\title{
Persuasive strategies in Mandela's No Easy Walk to Freedom
}

\author{
Ali Abdulhameed Faris \\ Dept of English, Faculty of Modern Languages and Communication, Universiti Putra Malaysia \\ E-mail: alifares1966@yahoo.com \\ Shamala Paramasivam (Corresponding Author) \\ Dept of English, Faculty of Modern Languages and Communication, Universiti Putra Malaysia \\ E-mail: shamala@upm.edu.my \\ Tan Bee Hoon \\ Dept of English, Faculty of Modern Languages and Communication, Universiti Putra Malaysia \\ E-mail: tanbh@upm.edu.my \\ Abdul Muati Zamri \\ Communication Dept, Faculty of Modern Languages and Communication, Universiti Putra Malaysia \\ E-mail: abmuati@upm.edu.my
}

\author{
Received: 05-07-2015 \\ Accepted: 10-10-2015 \\ Advance Access Published: October 2015 \\ Published: 01-01-2016 \\ doi:10.7575/aiac.ijalel.v.5n.1p.192 \\ URL: http://dx.doi.org/10.7575/aiac.ijalel.v.5n.1p.192
}

\begin{abstract}
Remarkable politicians are those who are skilled at communicating their ideas with a good sense of persuasion. The present paper is an endeavour to investigate the persuasive strategies of the African leader, Nelson Mandela, with reference to his address No Easy Walk to Freedom (1953). Johnstone's (2008) framework for persuasive strategies was used for the analysis. The findings demonstrate the use of three persuasive strategies - quasilogical, presentational and analogical. Quasilogical argumentation, which is based on rationality, was made through syllogism, enthymeme and causation. To create involvement, Mandela manipulated presentational persuasion via rhetorical deixes, metaphors, repetition and alliteration. Attempting to elevate the spiritual values of his addressees in regard to the cause of liberation and freedom, Mandela employed analogical persuasion by making a reference to the Bible. Of these three strategies, quasilogical and presentational strategies were the most manipulated by Mandela in the given speech to move his audience. Logic and rationality was used to motivate his audience to receive his claims about white supremacy, andemotions mainly grief and rage were evoked to energize the course of anti-white supremacy non-violent orchestrated struggle.
\end{abstract}

Keywords: language and politics, persuasion, persuasive strategies, political discourse, Nelson Mandela, No Easy Walk to Freedo

\section{Introduction}

It is worth noting that politics cannot be conducted without language. Politics is the most global sphere of human life. It has its concrete reflection in language in that it appears in vigorous logical and emotive terms. Language is the total device of politicians to provoke the mind and feeling of their audience and consequently to gain their persuasion (Newmark, 1991). Johnstone (2008) states that discourse is consciously designed for strategic aims, namely when addressers have the intention to persuade people to certain beliefs or a course of action. Johnson and Johnson (2000) believe that political discourse is intended to involve all citizens in the process of decision making, to gain the persuasion of others through valid information and logic, and to determine what course of action would be mostly influential in solving a social or a political problem. The aim of political discourse is basically to create consensus among citizens as to which course of action can be adopted to solve problems such as poverty, crime, social inequality and racism. In political discourse, problems are often presented and solutions are attached to people.

It could be noted that persuasion in political discourse of non-western leaders is an area which has received little research and is still being debated and refined. Thus, the current work is an attempt to highlight the process of persuasion in the discourse of a non-western political figure, Nelson Mandela. The iconicity of this African leader stems from his persuasive skills. Reviewing a great deal of literature on this global leader, it has been found that although there is much research on him from different perspectives and angles, such as his leadership, personal attributes, political ideology and political achievements, there is still little account on his persuasive discourse. The main objective of the present study is thus to identify the persuasive strategies employed by this leader to move his audience toward an action by investigating the speeches produced by him during four stages of his political career which lasted around fifty years and can be identified as: before his imprisonment, after his imprisonment, during his presidencyand after his 
presidency. The present paper, which is part of this larger study, presents the findings of the analysis of a speech delivered before his imprisonment.

\section{Related Literature}

\subsection{Political Discourse}

The term political discourse is simply used to refer to the discourse that is produced by politicians. For many political discourse analysts, this term is centred on the language of professional politicians or political institutions. However, pinning down what is political is an issue that is related to the viewpoint of the speaker. What seems to be political is not restricted only to the discourse produced by politicians since many decisions made by people everyday can be called political too. Such decisions are for instance those which revolve around globalization, racial discrimination, immigration, environment, poverty, assassination, crime, injusticeand terrorism. Crucial in this case is to realize that the actors of political process do not include only politicians, but also people, the masses, the public and citizens (Simpson and Mayr, 2010). According to Chilton and Schaffer (1997) the term political discourse can be defined in terms of certain issues, such as power, conflict or control and domination which are considered to be basic components of political discourse. The term political discourse, in the context of the current paper, is tackled in terms of the language of politicians, namely the language use of Nelson Mandela.

\subsection{Persuasion}

Persuasion as a term is defined variously by different linguists. It is an umbrella term which has powerful influence on all aspects of human life. Generally, it is a process aiming at changing individuals' or groups' attitudes or behaviour towards specific issues, ideologies or objects by employing written or spoken discourse (Reardon, 1981; Cacioppo, 1987; Borchers, 2002; Gass \& Seiter 2003). Although there is wide variety of definitions on the term 'persuasion', in the current study persuasion is viewed as a social act or event which promotes change; it intends to modify or change attitudes, values, behaviours, and to establish ideology and reconstruct reality (Cegalal, 1987; Woodward \& Denton, 1992; Johnstone, 1994; Perloff, 2003).

Mutz and Sniderman (1996) view that persuasion is the key target of political process; it is ubiquitous in every political interaction. It is worth noting that political issues arouse disagreement among politicians who, according to Heywood (2002), disagree on different matters such as the nature of the political system, the distribution of powers, the forms of government and so on. Miller, Coleman, Connolly and Ryan (2000) viewthat the elements of persuasion are involved in the political process and are the key to final decisions. Talking about the significance of persuasion in human life, Diamond and Cobb (1999) explain that throughout persuasion, addressers could change the views and attitudes of their addressees and shift their ideal points along the imagined line.

Johnstone (2008) expresses that for persuasion to take effect, in certain contexts, displays of rationality and logic are required, while emotions are needed in others. What is significant to realize in this regard is that the persuasive strategy which proves to be effective in one context might not be so in another. She identifies three linguistic strategies for persuasive discourse. They are quasilogical, presentational and analogical. These strategies are elaborated below:

\subsubsection{Quasilogical Strategy}

Persuaders of this strategy, who are affected by the structure and vocabulary of logic, try to create the impression that their arguments are rationally incontrovertible. More specifically, the fundamental goal of this strategy is to motivate receivers to approve the claims of the arguer throughout the power of rationality.

Johnstone (2008) explains that one technique of quasilogical argumentation is syllogistic reasoning. Syllogistic reasoning is a rational property which involves particular relationships, such as equality and numerical superiority. Quasilogical arguer tries to makes use of the wording and structures of formal logic and mathematics; however, quasilogical argumentation is not logical in the strict sense of the word. An example of logical argument based on syllogistic reasoning is: if A implies B and B implies C, then A implies C. Syllogistic reasoning, as a technique of quasilogical strategy, is a form of deductive logic that aims to reach a conclusion that is based on two or more ideas or plans that are assumed to be true. Axelord (2007) defines syllogism as a way of arguing which is constructed on three propositions; the first and the second are utilized by a speaker to prove that the third is true. The first and the second are premises, whereas the third is a conclusion.

Another type of logical argumentation is based on enthymeme. Enthymeme argument is based on probable premises rather than on true ones. Premises, with enthymeme, are sometimes unstated or implied because they are agreed upon as commonsense belief or supposition.

Johnstone (2008) demonstrates that in quasilogical persuasion, the arguer may utilize subordinate clauses to relate premises to conclusions, namely cause clauses, result clauses and conditional clauses. Premise is defined as a statement that functions as a reason for a certain conclusion (Johnstone, 2008). It is utilized by a speaker to prepare the listener to a certain conclusion. Constructing such arguments requires employing logical connectors such as since, as, provided that, if, because, so, and for.

\subsubsection{Presentational Strategy}

Presentational addressees are usually swept along by rhythmical flow of words or sounds. The overriding objective of this mode of persuasion is to make the arguer's claim present in the consciousness and mind of the hearer. 
Presentational persuader attempts to create involvement via various techniques such as alliteration, rhetorical deixes, metaphorand repetition.

Alliteration creates engagement through a flow of rhythmical sounds. It is a stylistic device whereby adjacent words are initiated with the same first consonant sound or different consonants having similar phonetic features such as $/ \mathrm{z} /$ and $/ \mathrm{s} /$, /f/ and /v/, and /b/ and /p/ (Johnstone, 2008).

Presentational arguers may manipulate terms like here, now, and this which are called, by Lakoff, "rhetorical deixes" (1974, p. 14 cited in Johnstone,2008). Fromkin and Rodman (1983) define deixes as words or expressions which cannot be interpreted without considering the circumstances of their utterances. Deixes, as pragmatic aspect, involve pronouns, such as his, your, their; proper names and expressions, such as that girl, this boy, those students, this woman; expressions of time, such as now, then, last week; expressions of place, such as here, this country, that place, those rooms; and expressions of direction, such as next to, after, before, etc.

Johnstone (2008) demonstrates that repetition of words and phrases play a vital role in the process of persuasion because it causes audience to feel strong emotions. In a similar vein, a presentational arguer may utilize metaphors for their ability to heighten persuasion by creating vivid pictures and conveying effective meanings in a concise way.

\subsubsection{Analogical Strategy}

Johnstone (2008) puts forward analogical strategy as the third strategy of persuasion; it is based on calling to mind a traditional wisdom explicitly or implicitly. In analogical argumentation, traditional wisdom is often produced in the form of fable-like story. Teaching by reminding audience of the time-tested values, or through the indirect mode of storytelling is the basic technique that arguers of analogical discourse adopt in the process of persuasion. Analogical arguers may make references to religious beliefs or faith. They may, for example, speak about biblical stories or passages. It is worth noting that audience, in the analogical discourse, are often indulged in making adductive leaps between past events and present issues. What can be recognized about this mode of persuasion is that the language of analogical discourse is similar to that of folktales.

\section{Methodology}

Being a discourse analytic study with a qualitative approach, where data collection entails "smaller selections of material, written or oral, which can be handled 'manually' by the researcher" (Angermuller, 2015, p. 512), the data for the present research entails one speech that is analysed manually by the researcher. The main criterion was to choose a speech before Mandela's imprisonment that was addressed during a grave and memorable moment in the history of South Africa. Accordingly, Mandela's No Easy Walk to Freedom was chosen for analysis. Denenberg (2014) explains that this speech was delivered in 1953 to a rally of 10,000. The essential message of this address was to call for protesting campaign wherein desegregation and democracy would be the basic demands of the protesters. It had profound impact on the social and political life of South Africans. It is available at (https://www.mandela.gov.za/mandela_speeches/ before/ 530921. tranvaal. htm).

As noted earlier, the research is qualitative and employs discourse analysis as a method to data analysis. Discourse analysis focuses on language above the level of sentence or clause and looks for patterns of language within and across texts while considering the relationship between language and the social and cultural contexts in which language is used (Coulthard, 1977; Stubbs, 1983; Paltridge, 2015). Accordingly, the unit of analysis, in the present study, is the sentence but the analysis is not limited to sentential analysis and goes beyond sentential boundaries to focus on the entire text or speech as a higher-level linguistic unit.Against such background, it could be realized that understanding a sentence requires more than knowing how to analyse it from a linguistic perspective. There must be therefore an understanding of the meaning of a sentence in relation to the exterior world in addition to the understanding of the meaning of words that a sentence is composed of. The study employs Johnstone's (2008) framework for the identification and analysis of linguistic persuasive strategies. As discussed above, this framework involves three persuasive strategies: quasilogical, presentational and analogical. The procedure of the analysis in this study is to identify and categorize the persuasive strategies and techniques as demonstrated in the framework, illustrated in Table 1.

Table 1. Persuasive Strategies and Techniques

\begin{tabular}{ll}
\hline Persuasive Strategy & \multicolumn{1}{c}{ Techniques } \\
\hline $\begin{array}{l}\text { Quasilogical Strategy } \\
\text { (arguments based on }\end{array}$ & The quasi-logical arguer utilizes the following techniques: \\
rationality) & a) informal use of Mathematical notion of transitivity or syllogistic \\
reasoning in constructing arguments, & b) logical connectives, such as "thus", "hence", "therefore", "accordingly", \\
"consequently", etc., \\
c) subordinate clauses that relate premises to conclusions, such as \\
"conditional clauses" and "cause clauses", \\
d)enthymeme, and \\
e) rhetorical questions, \\
so as to arrive at a valid logical conclusion.
\end{tabular}


Presentational Strategy The speaker can create involvement and arouse audience's consciousness by (arguments based on utilizing the following techniques:

involvement) a. rhythmical flow of words,

b. rhythmical flow of sounds or poetic alliteration,

c. imagery,

d. parallelism,

e. repeating claims, paraphrasing them, and calling attention to them,

f. visual metaphors ( "look", "see", "behold")

g. deixes, such as "here", "now", "this", etc.

h. simile, and

i. metaphor.

\begin{tabular}{|c|c|}
\hline $\begin{array}{l}\text { Analogical Strategy } \\
\text { (arguments based on } \\
\text { teaching using narrative) }\end{array}$ & $\begin{array}{l}\text { Analogical arguer constructs his argument throughout: } \\
\text { a. calling to mind a traditional wisdom in the mode of storytelling, } \\
\text { b. reminding audience of the time-tested values, } \\
\text { c. making use of formulaic language such as "that reminds me of ...","you } \\
\text { know that what they say", } \\
\text { d . utilizing the words and proverbs of the ancestors, and } \\
\text { e. referring to timeless past events ("once upon a time..."). }\end{array}$ \\
\hline
\end{tabular}

Johnstone (2008)

\section{Results and Discussion}

Excerpts from the given speech are analysed and discussed in terms of Johnstone's (2008) three persuasive strategies in question.

\subsection{Quasilogical Strategy}

Quasilogical discourse in the speech, under investigation, is expressed by vehicle of syllogism, enthymeme and causation.

Example 1 Syllogism

96 "But there is nothing inherently superior about the herrenvolk idea of the supremacy of the whites.

97 In China, India, Indonesia and Korea, American, British, Dutch and French Imperialism, based on the concept of the supremacy of Europeans over Asians, has been completely and perfectly exploded.

98 In Malaya and Indo-China British and French imperialisms are being shaken to their foundations by powerful and revolutionary national liberation movements.

99 In Africa, there are approximately 190,000,000 Africans as against 4,000,000 Europeans.

100 The entire continent is seething with discontent and already there are powerful revolutionary eruptions in the Gold Coast, Nigeria, Tunisia, Kenya, the Rhodesias and South Africa.

101 The oppressed people and the oppressors are at loggerheads.

102 The day of reckoning between the forces of freedom and those of reaction is not very far off.

103 I have not the slightest doubt that when that day comes truth and justice will prevail.

In Example 1, Mandela looks upon the issue of white supremacy as one of the challenges that are encountered by people in different parts of the world. According to him, the ideology of the European superiority or white supremacy has swept through extensive parts of our world. In response, the people who have suffered racial segregation have not kept passive. Rather they have voiced their indignation against the different forms of racial injustice and submission by a wave of defiance and revolutions that prevailed among many countries. In his argument, Mandela tries to persuade his audience syllogistically by presenting two premises and a conclusion. The two premises, which are hypothesized to be constructed on causation, give the conclusion in question. They are structured as subordinate clauses headed by the logical connector because. The two premises and the conclusion can be deduced as follows:

First Premise:

Because the ideology of white supremacy is deeply rooted in different parts of the globe,

Second Premise:

and,because the ideology of white supremacy is a striking violation of human rights and dignities,

Conclusion:

Therefore, powerful revolutions erupted across the world to end white supremacy.

What can be recognized from the first premise (the basic premise) is that the ideology of white supremacy has spread through the world. The Europeans have got supremacy over Asians, as in India, China, Indonesia, and Korea and over people in many parts of America and Africa (line 97). The second premise (the minor premise) touches the truth that the 
ideology of white supremacy has been a gross violation of human rights and human dignities. Fredrickson (1981) considers the ideology of white supremacy as one form of racism. It is centred on the belief that the whites are superior to the non-whites in their characters and attributes. Based on this belief, the advocates of this ideology, according to Fredrickson (1981), are on the assumption that the whites have the right to rule the non-whites economically, socially and politically. Mills (2003) expresses that the ideological foundations of white supremacy is dated back to the $17^{\text {th }}$ century. It was a paradigm that affected the international and intra-national relations from the $17^{\text {th }}$ century up to the late $20^{\text {th }}$ century. One of the flaring examples of this ideology is the Apartheid in South Africa which had existed for decades before it was abolished officially in 1994.

The above two premises lead to the inevitable conclusion that there has been an angry response from peoples who were oppressed by the different forms of European domination across the world. Their indignation was voiced by defiance campaigns and revolutions, as in Malaya Peninsula (line 98), which was under the British control from $18^{\text {th }}$ to $20^{\text {th }}$ centuries (Osborne, 2000). Meanwhile, there was a resistance war in the so called French Indo-China. Buttings (1972) states that the French Indo-China is a political term that was used to refer to contemporaryVietnam. The people of this region started their resistance war against the French domination from 1946 to 1954. Buttings (1972) reports that the resistance war extended to include Laos and Cambodia which were French Indo-China protectorates.He notes that in July 1945, the part of Indo-China lying south of Latitude 16 north was decided, at the Postdam Conference, to be placed under the British control.

Based on the two aforementioned premises, Mandela puts forward a concrete conclusion whereby he goes beyond the borders of South Africa to consider racial domination as a global issue that has adversely affected the sovereignty, dignity and character of many countries. Consequently, strong anti-racial movements have come into existence determining to fight European domination to the death for the sake of freedom, justice and liberation, as it is the case in Gold Coast, Nigeria, Tunisia, Kenya, the Rhodesia and South Africa (line 100). Mandela appears to be highly optimistic that revolutions will put an end to European domination and the will of peoples will triumph at the end of the way (line 103).

Another instance of syllogism can be perceived in lines 1-5 (see speech in Appendix) where two premises and a conclusion can be deduced:

First Premise:

Since the white authorities have followed vehemently various strategies to impoverish, exclude, exploit and dominate the blacks.

Second Premise:

and, since the repression of the white has grown in volume and intensity.

Conclusion

An upsurge of national consciousness has raised among the blacks who have started speaking the language of action.

Example 2 Enthymeme

12 Defiance was a step of great political significance.

13 It released strong social forces which affected thousands of our countrymen.

14 It was an effective way of getting the masses to function politically; a powerful method of voicing our indignation against the reactionary policies of the Government.

15 It was one of the best ways of exerting pressure on the Government and extremely dangerous to the stability and security of the State.

16 It inspired and aroused our people from a conquered and servile community of yesmen to a militant and uncompromising band of comrades-in-arms.

In Example 2, Mandela puts forward an explicit premise, "Defiance was...political significance" (line 12). The stated premise is that the defiance had great political significance. This premise is followed by four conclusions. The first is that the defiance resulted in creating social forces which could move thousands of countrymen (line 13). The second is that the defiance promoted the South Africans to think about the effect of politics on their life and to make decisions (line 14, "It was...function politically"). The third is that the defiance was an influential way of expressing the indignation of the masses against the racial policies and measures of the racial government (line 14 "a powerful method...the government").The fourth is that the defiance caused a great deal of pressure on the government and it was a serious threat to the stability and security of the racial state, noted in line 15, "It was...the state". The last conclusion generated by the given premise is that the defiance succeeded in transforming the South Africans from conquered dominated people to defying and challenging militants who eventually resorted to force to achieve their own legitimate goals (line 16 "It inspired...band of comrades-in-arms").

The above conclusions are supposed to be based on two premises, one is explicit which is "Defiance was...political significance" (line 12), whereas the second, which is supposed to be produced before this explicit one, is absent. It is assumed to be a premise which works together with the explicit one. It is arguably supposed to be that "The South Africans resolved to go on defiance as a result of the aggravated policies of oppression and social inequality". It is 
implicit because it is present in the minds of the receivers. More specifically, it is part of the shared knowledge between Mandela and his audience. It could be noted that Mandela, by manipulating the explicit premise and conclusions in the above extract, tries to make his argument be based onreasoning. The power of reasoning, resulted from enthymeme, may promote his addresseesto think rationally of the significance of the defiance as one strategy of liberation and freedom.

The use of enthymeme is also obvious in lines 56-61 (see speech in Appendix). In these lines, it could be perceived that the explicit premise is "The purchasing power of the masses is progressively declining and the cost of living is rocketing", whereas the implicit premise is "Because of the institutionalized policies of exclusion and domination of white authorities, the black people have undergone terrible living conditions".

Example 3 below highlights the logical technique of causation. In this example, the technique of using subordinate clauses which relate premises to conclusions is intensified with manipulation of cause clause. The technique of causation, according to Mackie (1988), is a rational technique that is used by speakers to express the relation between two events. The first is the cause whereas the second is the effect. Miller and Johnson-Laird (1976) look upon causation as a relation which involves a factor and a phenomenon. The factor stands for the cause, while the phenomenon stands for the effect. Causes and effects, according to Mackie (1988), are subjected to changes, events, and processes. Mandela, in his argument, attempts to persuade his audience rationally throughout a series of cause and effect clauses. Mandela starts his argument by giving an introduction to his long argument constructed on cause and effect. The basic idea of this introduction is that he and his comrades Kotane, Marks, Bopape, and Tloome have been banned by the apartheid authorities to attend any gathering (line 163). The judgment has deprived him of joining his masses and communicating with them the challenges that face South Africa. Then, he goes on to speak out the causes that have led to the effect which is his prohibiting from joining and communicating with his audience. The first cause is explained in line 164, "because we...our country". Obviously, the first cause of the effect is his leading role in fighting the racial forces in support of the liberation and freedom of the South Africans. The second cause, "...and because we...sex or language" demonstrated in lines 164, is Mandela's determination to fight consistently for the cause of social equality and freedom regardless of race, color, sex and language. In line 165, Mandela produces a third cause for his being banned to be in contact with his masses in an argument based on cause and effect construction using the logical connector for, in "We are exiled from our own people for...imperial powers" (line 165). According to Mandela, the third cause that has promoted the racial government to separate him from his audience is his strong opposition to the cruel and inhuman agenda of the imperialist America and its satellites to drag the world into the rule of violence and annihilation. To force domination upon the world, the imperialist powers usually resort to use different kinds of weapons such as napalm, hydrogen and the cobalt bombs which are considered to be mass deconstruction weapons. Using such weapons, according to Mandela, is a revelation of the brutal and violent nature ofAmerica and its allies.

\section{Example 3 Causation}

163 Kotane, Marks, Bopape, Tloome and I have been banned from attending gatherings and we cannot join and counsel with you on the serious problems that are facing our country.

164 We have been banned because we champion the freedom of the oppressed people of our country and because we have consistently fought against the policy of racial discrimination in favour of a policy which accords fundamental human rights to all, irrespective of race, colour, sex or language.

165 We are exiled from our own people for we have uncompromisingly resisted the efforts of imperialist America and her satellites to drag the world into the rule of violence and brutal force, into the rule of the napalm, hydrogen and the cobalt bombs where millions of people will be wiped out to satisfy the criminal and greedy appetites of the imperial powers.

166 We have been gagged because we have emphatically and openly condemned the criminal attacks by the imperialists against the people of Malaya, Vietnam, Indonesia, Tunisia and Tanganyika and called upon our people to identify themselves unreservedly with the cause of world peace and to fight against the war policies of America and her satellites.

167 We are being shadowed, hounded and trailed because we fearlessly voiced our horror and indignation at the slaughter of the people of Korea and Kenya.

It could be noted that Mandela, in the above argument, describes America and its satellites as imperialist powers. Fay and Daniel (2012) explain that imperialism, as a political term, is used to refer to the western political and economic dominance throughout colonization in the $19^{\text {th }}$ and $20^{\text {th }}$ centuries. The ideology of imperialism, which is based on the idea of superiority, promotes expansionist policies to be practiced by a big power to control and rule a country or a group of people. What can be recognized from the argument of this example is that Mandela tries to arouse the rational of his receivers, via the use of premises and conclusions, to think over the racial and inhuman policies of imperialism in the world.

It can be observed that Mandela draws a fourth cause and effect argument in line 166, "We have been gagged because... her satellites". In this argument, he gives a fourth cause for his being prevented to counsel with the masses; it is his open and unreserved calling upon the public to condemn and attack the expansionist and violent policies of 
America and its satellites in a number of countries across the world such as Malay, Tunisia, Indonesia, Vietnam and Tanganyika.

It is worth noting that Mandela goes beyond the borders of South Africa when he emphasizes his solidarity to the nations that have been brutalized by the imperialist powers. His solidarity to these dominated nations can be realized as a cause for his being shadowed, trailed and hounded by the racial authorities. It could be noted that Mandela makes this argument of cause and effect in line 167, "We are being shadowed, hounded and trailed because...Korea and Kenya", where he reveals his concerns about the nations which are economically, socially, and geographically discriminated and slaughtered by the western dominating powers. It could be realized that throughout the technique of cause and effect, Mandela makes a reference to a number of oppressed and dominated nations across the world. It is a mode of quasilogical persuasion which may help Mandela to make his masses think of him as a universal leader. Stengal (2009) sees that the universality of Mandela stems from the fact that he was fighting in favor of every human being that was treated as he was.

Three more examples of causation can be seen in the given speech:first, in line 26 (see Appendix) wherein the cause connector for is used to give the effect that forty-seven leading members from both African National Congress and South African Indian Congress were arrested for launching defiance campaign; second, in line 63(see Appendix), where the cause clause is headed by the cause connector because to give the terrible effect of white domination on the life of the blacks;third, in line 172 (see Appendix) where causation is utilized twice by Mandela, in the same context, to motivate his masses to think logically of the causes of his persecution inside his home; one cause is that he has urged people to challenge the racial forces and the second cause is that he has declared openly his solidarity and support to the cause of the Kenya people who have been under British colonialism.

\subsection{Presentational strategy}

It could be noted that Mandela, in the speech under study, utilizes four techniques to create involvement. Theses presentational techniques are: rhetorical deixes, metaphor, repetition and alliteration.

\section{Example 4 Rhetorical Deixes}

1 Since 1912 and year after year thereafter, in their homes and local areas, in provincial and national gatherings, on trains and buses, in the factories and on the farms, in cities, villages, shanty towns, schools and prisons, the African people have discussed the shameful misdeeds of those who rule the country.

2 Year after year, they have raised their voices in condemnation of the grinding poverty of the people, the low wages, the acute shortage of land, the inhuman exploitation and the whole policy of white domination.

3 But instead of more freedom repression began to grow in volume and intensity and it seemed that all their sacrifices would end up in smoke and dust.

4 Today the entire country knows that their labours were not in vain for a new spirit and new ideas have gripped our people.

5 Today the people speak the language of action: there is a mighty awakening among the men and women of our country and the year 1952 stands out as the year of this upsurge of national consciousness.

In Example 4, Mandela employs a variety of presentational techniques that create involvement. This extract is charged with different rhetorical deixes such as pronouns, proper names and expressions of time and place. Examples of pronouns are "their homes" in line 1, "their voices" in line 2, "their sacrifices" in line 3, "their labors" in line 4. Mandela utilizes these deixes to assert that the damage and harm caused by the unjust and inhuman policies of the apartheid struck all parts of South Africa and the majority of South Africans.

The second type of rhetorical deixes, employed by Mandela, is expression of time such as "since 1912 and year after year" in line 1, "today" in line 5 and "the year 1952" in line 5. Employing time deixes represents an indication of the South Africans' total shift in their struggle against the apartheid. The time deixis "since 1912" refers to the time when South Africans started discussing the unfair policies of the racial system, whereas the time deixis "today", which refers to the year 1952, signifies the heightening awareness of South Africans in that it was the time when they got face to face with the racial forces. It was the time when they transformed their rejection to the apartheid into action. Using such deixes could help Mandela to evoke the passions of the South Africans against the unjust measures of the white government.

The third type of deixes, utilized by Mandela, is proper names such as "farms" and "cities", "villages", "shanty towns", and "schools and prisons" in line 1, and "men and women" in line 5. By proper name deixes, Mandela may be able to persuade his audience who are adversely affected by the policies of the racial system that South Africans have resolved to take action and raise their voice against the authorities of apartheid. Fromkin and Rodman (1983) state that understanding deixes is based on the pragmatic knowledge that the speaker and the receiver share about the expressions. 
One more intensive example of rhetorical deixes is obvious in lines 66-73 (see Appendix) where rhetorical deixes of proper nouns, pronouns and expressions of time are manipulated to uncover the inhuman exploitation of black labours by white farmers.

Example 5 Metaphor

17 The entire country was transformed into battle zones where the forces of liberation were locked up in immortal conflict against those of reaction and evil.

18 Our flag flew in every battlefield and thousands of our countrymen rallied around it.

19 We held the initiative and the forces of freedom were advancing on all fronts.

20 It was against this background and at the height of this Campaign that we held our last annual provincial Conference in Pretoria from the 10th to the 12th of October last year.

21 In a way, that Conference was a welcome reception for those who had returned from the battlefields and a farewell to those who were still going to action.

What is noticeable in the above extract is the intensive utilization of metaphors. Lakoff and Johnson (2003) state that metaphors play a significant role in the process of persuasion. They make abstract things more familiar and concrete. They are also essential political tools of political persuasion because they help politicians to transfer meaning from politics as a complex domain to a simpler one as there is a sharedsystem of beliefs and values between the speaker and his recipients. In this extract, Mandela employs metaphors intensively. For example, in line 17, he utilizes the metaphor "battle zone" to compare South Africa, as a whole, to a battlefield. By utilizing this metaphor, Mandela tries to emphasize that the state of rejection and opposition to the apartheid had spread through the whole country. Meanwhile, this metaphor creates the impression that the tyranny of the apartheid was lurking everywhere in South Africa. The "forces of liberation", in line 17, is a metaphor used by Mandela to describe those who were fighting the apartheid as fighters for the sake of liberation and freedom. Hence, the phrase "forces of liberation" is used metaphorically to assert that the objectives of fighters were to free themselves and their country from the control and domination of the racial system. It could be realized that the metaphor "forces of liberation" can be accounted for as a metaphor of defying and challenging. Moreover, it is a declaration of legitimizing the anti-apartheid activities and operations that have been conducted by the South Africans. In line 17, Mandela uses the word "immortal" imaginatively to describe the persistency and consistency of the conflict. He endeavors to convey the idea that the conflict will last forever until achieving the whole aspirations of South Africans; it will be remembered by the present and future generations.

Having described the anti-apartheid fighters as "forces of liberation", Mandela goes on to compare the racial forces as the forces of "reaction and evil", line 17. Employing this metaphor may help him to urge the masses against the wickedness and cruelty of the apartheid forces. Moreover, it could make the addressees realize that the nature of the apartheid is in opposition to any social or political progress.It is worth noting that Mandela utilizes two contradictory metaphors in the same utterance, the first is "forces of liberation" which is used to describe the South African antiapartheid fighters, whereas the second is "reaction and evil", which is manipulated to describe the forces of apartheid. In a similar vein, he compares the anti-apartheid fighters to the "forces of freedom", in line 19. Using this metaphor, Mandela could confirm that the anti-apartheid fighters are not outlaws or gangsters but they are freedom and liberation seekers.

It could be recognized that Mandela intensifies the use of metaphors so as to achieve a high sense of persuasion. He, then, goes on referring to an important incident which occurred during that eventful period which was fraught with action movement and militant operations against the forces of segregation. It is the annual conference that has been held by the two anti-apartheid organizations: the African National Congress and the South African Indian Congress. What is important in this regard is that the conference is described metaphorically by Mandela as a "welcome reception", and as a "farewell", line 21. It is a "welcome reception" because it has received warmly those who have come from the fronts and as a "farewell" as it has posed a motivation for the others who have been on their way to join those fronts.

One more example of metaphor can be seen in line 118 (see Appendix) where racial authorities of South Africa are metaphorically described as "gangsters", that is as criminals who are members of a gang having common activities, organizational structure, and code of conduct.

\section{Example 6 Repetition}

46 We had to recuperate our strength and muster our forces for another and more powerful offensive against the enemy.

47 To have gone ahead blindly as if nothing had happened would have been suicidal and stupid.

In Example 6, Mandela makes use of repetition as a technique of involvement. He tries to create engagement by repeating the pronoun "our" in "our strength" and "our forces" in line 46. Repeating the pronoun "our" can provide a tool for promoting the audience to rally around their leadership and to get involved in the inhuman policies and measures of the racial system which is deeply rooted in South Africa. Moreover, the repetition of the pronoun "our" emphasizes a sense of oneness between the speaker and his audience. He tries to persuade his receivers that their struggle against the apartheid is not chaotic or purposeless, rather it is well-organized and well-planned.That "We had to 
recuperate our strength and muster our forces" is a demonstration that the forces of freedom and liberation have been united behind their leaders in fighting the forces of apartheid. Moreover, Mandela, via the repetition of the pronoun "our", tries to convey the message that the forces of freedom have been well-prepared in dealing with the challenges they could face and have been highly dedicated to ridding their nation of the tragedies of the racial injustice. Tannen (1989) expresses that repetition, as it has a key role in the process of persuasion, signifies the multiplying instances of an idea and it is utilized for attracting attention and emphasizing meaning.

Two more examples of repetition are also found in this speech. In line 137 (see appendix), repetition is seen in the word "every" which is used in: "every home", "every shack" and "every mud structure". Repeating this word thrice in the same context may help Mandela to emphasize the idea that the racial state should be resisted by all people of South Africans. In line 141, the word "every" is repeated twice, it can be noted in:" every home" and "every shack or rickety structure". Repeating the word every, in this context, could help Mandela to emphasize the idea that black parents themselves must hold the responsibility of teaching their sons at homes or at shacks since their sons are denied the right to get proper education by racial authorities.

\section{Example 7 Alliteration}

158 Here in South Africa, as in many parts of the world, a revolution is maturing: it is the profound desire, the determination and the urge of the overwhelming majority of the country to destroy forever the shackles of oppression that condemn them to servitude and slavery.

Various presentational techniques are employed by Mandela in this speech so as to get his audience engaged in their cause. Employing a variety of involvement techniques may help Mandela to add a level of power to his speech and to make his messages more engaging, catchy and memorable. One obvious technique of involvement utilized in this extract is poetic alliteration which can be noted in "servitude and slavery" in line 158. The two words are alliterated with the sound /s/. Lanham (1991) defines alliteration as a stylistic device whereby a speech sound is repeated in a sequence of words which are adjacent. In addition to the sense of musicality it provides the message with, alliteration makes the messages more memorable, interesting and appealing. Thus, it entails a high sense of persuasive content. By using alliteration, Mandela tries to send his audience away feeling the volume of oppression and injustice they are subjected to. He endeavours to inspire his masses to keep on revolting until destroying all shackles put on them by the advocates of segregation.

Two other examples of alliteration are vivid in lines146 and 166 (see Appendix). In line 146, the alliterated words are "splitters and saboteurs", they are alliterated with the sound /s/. By means of these alliterated words, Mandela tries to persuade his audience that he has been aware of those who aim to spoil the image of the anti-apartheid movement by committing sabotage. In line 166, the alliterated words are "Tunisiaand Tanganyika", they are alliterated with the sound $/ \mathrm{t} /$. By uttering these two countries which have been dominated by foreign powers, Mandela confirms his universality that he is against domination of every nation over the world.

\subsection{Analogical Strategy}

The analogical discourse of Mandela in the speech, under study, is obvious by his attempt to make allusion to the Bible

\section{Example 8 Biblical reference}

73 You can see that "there is no easy walk to freedom anywhere, and many of us will have to pass through the valley of the shadow (of death) again and again before we reach the mountain tops of our desires.

Mandela ends his speech with a reference to a biblical text which is of highly didactic value. By alluding to the "valley of the shadow of death", in line 73, Mandela tries to raise the morale of his audience. The text "Even though I walk through the valley of the shadow of death, I fear no evil, for You are with me; Your rod and your staff, they comfort me", is from the Bible, Psalm 23: 4 (Bailey, 2015, p. 32). MacMillan (1988) expresses that God, in Psalm 23, is portrayed as a shepherd who kindly feeds and leads his flock. MacMillan views that analogizing God to a shepherd signifies that $\mathrm{He}$ is a caretaker in addition to his being a protector.Bosch (2011) explicates that the "flock of sheep" is used to denote the true believers who are harmless, calm and kind. Thus, they are under the watchfulness, protection and care of God. MacMillan (1988) explains that the word "death" is not used to mean death itself, rather it is imaginatively manipulated to refer to any path of tragedy, dilemma, sorrow, grief, sadness, misery or loss. Yet, the true believers do not fear death, which is described as a valley that is really gloomy and miry but, meanwhile, fruitful, because it gets them safe to the mountain, the heaven, where the care, goodness and grace of God will follow. Mentioning this Biblical text may help Mandela to persuade his audience that they have to make sacrifices so that they could defeat their enemies. Their death does not mean the end of life, rather it is the outset of their salvation.Equally significant, Mandela, via the employment of this text, attempts to emphasize the idea that South Africans are in danger which is as deep as a valley, as dark as a shadow, and as dreadful and awful as death itself. Nevertheless, they do not fear death and never give up hope of having their liberation and freedom at the end of the day. They have every confidence in their cause to such a degree that they are ready to die for it since they believe that death itself will work good for them. 
The study showed that Mandela utilized the three persuasive strategies, quasilogical, presentational and analogical. A summary of the frequency of these strategies is displayed in Table 1.

It could be observed that quasilogical discourse was presented, most frequently through the manipulation of causation, followed by syllogism and enthymeme. Presentational discourse was evident most frequently through repetition, followed by rhetorical deixes, metaphor and alliteration. The practicability of the analogical discourse was obvious when Mandela made a reference to the Bible. Of the three strategies, it could be observed that quasilogical strategy and presentational strategy were the most employed by Mandela. Presentational argumentation aimed to incite the patriotism of the blacks and to provoke their anger and resentment against white supremacy, whereas Mandela's quasilogical discourse was evident by the technique of premises and conclusions and the technique of cause and effect where he tries to persuade his receivers to rationalize the inhuman measures of the racial state. The two strategies worked actively, in the speech under study, to formulate the persuasive discourse of Mandela.

Table 2 Persuasive strategies and techniques in No Easy Walk to Freedom

\begin{tabular}{|c|c|c|}
\hline $\begin{array}{l}\text { Persuasive } \\
\text { Strategies }\end{array}$ & Persuasive Techniques & Frequency/ Line Ref \\
\hline \multirow[t]{3}{*}{ Quasilogical } & Syllogism & $\begin{array}{c}2 \\
\text { (lines1-5, 96- 103) } \\
\end{array}$ \\
\hline & Enthymeme & $\begin{array}{c}2 \\
(\text { lines } 12-16,56-61) \\
\end{array}$ \\
\hline & Causation & \begin{tabular}{l}
\multicolumn{1}{c}{4} \\
(lines 26, 63, 163-167, \\
172)
\end{tabular} \\
\hline \multirow[t]{4}{*}{ Presentational } & Rhetorical Deixes & $\begin{array}{c}2 \\
(\text { lines } 1-5,66-73) \\
\end{array}$ \\
\hline & Metaphor & $\begin{array}{c}2 \\
\text { (lines 17-21, 111) }\end{array}$ \\
\hline & Repetition & $\begin{array}{c}3 \\
(\text { lines } 46,137,141) \\
\end{array}$ \\
\hline & Alliteration & $\begin{array}{c}2 \\
2 \\
(\text { lines } 146,166) \\
\end{array}$ \\
\hline Analogical & Biblical Reference & $($ line 173) \\
\hline
\end{tabular}

\section{Conclusion}

The present study is designed to reveal how language is used by Mandela to persuade his audience to resist the different forms of oppression and injustice practiced by racial authorities in South Africa. This study is an attempt to explore the persuasive acts in Mandela's memorable speech No Easy Walk to Freedom (1953). The analysis is done in terms of Johnstone's (2008) three persuasive strategies: quasilogical, presentational, and analogical. The findings demonstrate that the three persuasive strategies were utilized in the discourse of Mandela. Of the three strategies, the quasilogical and presentational are the most utilized by Mandela. Quasilogical strategies entailed the use of logical tools: causation, the most, followed by syllogism and enthymeme. Utilizing such arguments may have helped Mandela to drive his masses to think rationally over the ideology of white supremacy and to incite his receivers to think about the anti-racial defiance and revolutions as a reaction to the white supremacy. In contrast to quasilogical argumentation which is based on rationality, Mandela utilized presentational argumentation as a mode of persuasion that is based on involvement and engagement. Examples of the utilized presentational techniques were repetition, the most frequently used, followed by rhetorical deixes, metaphor and alliteration. These techniques were used to address the emotions of his audience so as to get them involved in different issues that concern their existence under the domination of the apartheid.The findings also revealed that Mandela utilized analogical persuasion to consolidate his claims by referring to a biblical text. Making a reference to the Bible may have helped him to persuade his audience to maintain a sacred image of their cause.

By and large, it could be concluded that in addition to his upbringing, education, culture and political career, which have played crucial role in shaping his discourse, Mandela has proved to possess remarkable persuasive skills which have helped to substantiate his iconicity as a global and phenomenal political leader. The strategic function of his persuasive discourse was to incite the masses to go on non-violent resistance against the different forms of oppression and social inequality practiced by the authorities of white supremacy. He was not only a great communicator but also a great persuader who was able to get his masses through logical, emotional and didactic arguments. It could be observed that out of the three persuasive strategies employed in the speech, quasilogical and presentational strategies are the most manipulated. Mandela uses logic and rationality to motivate his audience to receive his claims about white supremacy, and he stresses the role of emotions mainly grief and rage to energize the course of anti-white supremacy non-violent 
orchestrated struggle. What is significant to be realized about the three given persuasive strategies is that they are universal and practicable; they are utilized by politicians of different ages to effectively influence the beliefs, attitudes and values of the their receivers.

\section{References}

Angermuller, J. (2015). Discourse Studies. In Wright, J.D. (ed.). International Encyclopedia of the Social \& Behavioral Sciences (2nd ed.). Amsterdam: Elsevier. pp510-515.

Audi, R. (ed.) (1991). The Cambridge dictionary of philosophy (2 $2^{\text {nd }}$ ed.). Cambridge: Cambridge University Press.

Axelord, A. (2007). Getting you every day: mastering the lost art of pure persuasion. Cambridge:Cambridge University Press.

Baily, K. (2015).The Good shepherd: A thousand-year journey from psalm 23 to the newtestament. London: Graphicraft Ltd.

Borchers, T.A. (2002). Persuasion in the middle age. Boston: Me GrawHall.

Bosch, D. (2011). Transforming mission: paradigm shifts in theology of mission. New York: Orbis Books.

Cacioppo, J. \& Morris, K. (1983).Effects of need for cognition on message evaluation, recall, and persuasion. Journal of Personality and Social Psychology, 45, 805- 818.

Cegalal, D. (1987). Persuasive communication: Theory practice. Edina, MN: Burgers International.

Chilton, P. \& Schaffer, C. (1997).Discourse and politics. In T. van Dijk (ed.).Discourse as Social Interaction, 2, 206231.

Coulthard, M. (1977).An Introduction to discourse analysis. London: Longman.

Denenberg, B. (2014). Nelson Mandela: No easy walk to freedom. New York: Scholastic Inc.

Diamond, G. \& Cobb, M. (1999). The Candidate as catastrophe: Latitude theory and the problems of political

persuasion. In Mutz, D. C., Sniderman, P. M. \& Brody R. A. (eds.) Political persuasion and attitude change (pp. 225247). Ann Arbor: University of Michigan Press.

Fay, R.\& Daniel G. (2012).Discovering imperialism: Social democracy to world warl. Chicago: Heymarket Books.

Fromkin, V. \& Rodman, R. (1983).An Introduction to language. New York: Dryden Press.

Gass, R. H. \&Seiter J.S. (2003).Persuasion: Social influence and compliance gaining. Boston MA: Allyn and Bacon.

Heywood, A. (2002). Politics. New York: Palgrave.

Johnstone, B. (1994). Repetition in discourse: interdisciplinary perspectives. Advances in Discourse Processes, 1, $2-23$.

Johnstone, B. (2008). Discourse Analysis. Oxford: Blackwell Publishing.

Lakoff, G.\& Johnson, M. (2003).Metaphor we live by. London: Chicago University Press.

Lakoff, R. (1974). Remarks as this and that. Chicago Linguistics Society, 10, 345-356.Chicago: Chicago University Press.

Lanham, R. (1991). A Hand list of rhetorical Terms. Los Angeles: University of California Press.

Mackie, J. (1988). The Cement of the universe: A Study in causation. Oxford: Clarendon Press.

MacMillan, J. (1988). The Lord of shepherd. Bryntirion: Evangelical Press of Wales.

Mandela, Nelson (1953).No easy walk to freedom. Retrieved March 22, 2015 fromhttps://www.mandela.gov.za/ Mandela_speeches/before/530921. Tranvaal.htm.

Miller, D., Coleman, J., Connolly, W. \& Ryan, A. (eds.) (2000).The Blackwell encyclopedia of political thought, 390310. Oxford: Blackwell Publishers.

Miller, G. \& Johnson-Laird, P. (1976). Language and perception. Cambridge: Cambridge University Press.

Mutz, D.\&Sniderman P. (1996). Political persuasion and attitude change. Michigan: University of Michigan Press.

Newmark, P. (1991). About translation. Clevendon: Multilingual Matters Limited.

Paltridge, B. (2015). Discourse Analysis: An introduction. London: Bloomsbury Academic.

Perloff, R. M. (2003). The Dynamics of persuasion: Communication and attitude in the $21^{\text {st }}$ century. Hillsdale, NJ:LawrenceIbErbaum.

Reardon,K.. (1981). Persuasion: Theory and context. London: Sage Publication.

Simpson, P. \&Mayr, A. (2010). Language and power. London: Routledge.

Stubbs, M. (1983).Discourse analysis: The Sociolinguistic analysis of natural languages. Oxford: Basil Blackwell Publisher Limited.

Woodward, G. \& Denton, R. (1992). Persuasion and influence inAmerican Life. Philadelphia: John Benjamines B.V. 
Appendix

FULL TEXT: No Easy Walk To Freedom

2011-01-24 15:34

Presidential Address1 by Nelson R. Mandela to the ANC (Transvaal) Congress

21 September 1953

Line

1

\section{Speech Content}

Since 1912 and year after year thereafter, in their homes and local areas, in provincial and national gatherings, on trains and buses, in the factories and on the farms, in cities, villages, shanty towns, schools and prisons, the African people have discussed the shameful misdeeds of those who rule the country.

Year after year, they have raised their voices in condemnation of the grinding poverty of the people, the low wages, the acute shortage of land, the inhuman exploitation and the whole policy of white domination.

But instead of more freedom repression began to grow in volume and intensity and it seemed that all their sacrifices would end up in smoke and dust.

Today the entire country knows that their labours were not in vain for a new spirit and new ideas have gripped our people.

Today the people speak the language of action: there is a mighty awakening among the men and women of our country and the year 1952 stands out as the year of this upsurge of national consciousness.

In June, 1952, the AFRICAN NATIONAL CONGRESS and the SOUTH AFRICAN INDIAN CONGRESS, bearing in mind their responsibility as the representatives of the downtrodden and oppressed people of South Africa, took the plunge and launched the Campaign for the Defiance of the Unjust Laws.

Starting off in Port Elizabeth in the early hours of June 26 and with only thirty-three defiers in action and then in Johannesburg in the afternoon of the same day with one hundred and six defiers, it spread throughout the country like wild fire.

Factory and office workers, doctors, lawyers, teachers, students and the clergy; Africans, Coloureds, Indians and Europeans, old and young, all rallied to the national call and defied the pass laws and the curfew and the railway apartheid regulations.

At the end of the year, more than 8,000 people of all races had defied.

The Campaign called for immediate and heavy sacrifices.

Workers lost their jobs, chiefs and teachers were expelled from the service, doctors, lawyers and businessmen gave up their practices and businesses and elected to go to jail.

Defiance was a step of great political significance.

It released strong social forces which affected thousands of our countrymen.

It was an effective way of getting the masses to function politically; a powerful method of voicing our indignation against the reactionary policies of the Government.

It was one of the best ways of exerting pressure on the Government and extremely dangerous to the stability and security of the State.

It inspired and aroused our people from a conquered and servile community of yesmen to a militant and uncompromising band of comrades-in-arms.

The entire country was transformed into battle zones where the forces of liberation were locked up in immortal conflict against those of reaction and evil.

Our flag flew in every battlefield and thousands of our countrymen rallied around it.

We held the initiative and the forces of freedom were advancing on all fronts.

It was against this background and at the height of this Campaign that we held our last annual provincial Conference in Pretoria from the 10th to the 12th of October last year.

In a way, that Conference was a welcome reception for those who had returned from the battlefields and a farewell to those who were still going to action.

The spirit of defiance and action dominated the entire conference.

Today we meet under totally different conditions.

By the end of July last year, the Campaign had reached a stage where it had to be suppressed by the Government or it would impose its own policies on the country.

The government launched its reactionary offensive and struck at us.

Between July last year and August this year forty-seven leading members from both Congresses in Johannesburg, Port Elizabeth and Kimberley were arrested, tried and convicted for launching the Defiance Campaign and given suspended sentences ranging from three months to two years on condition that they did not again participate in the defiance of the unjust laws.

In November last year, a proclamation was passed which prohibited meetings of more than ten Africans and made it an offence for any person to call upon an African to defy.

Contravention of this proclamation carried a penalty of three years or of a fine of three hundred pounds. 
29 In March this year the Government passed the so-called Public Safety Act which empowered it to declare a state of emergency and to create conditions which would permit of the most ruthless and pitiless methods of suppressing our movement.

30 Almost simultaneously, the Criminal Laws Amendment Act was passed which provided heavy penalties for those convicted of Defiance offences.

31 This Act also made provision for the whipping of defiers including women.

32 It was under this Act that Mr. Arthur Matlala who was the local [leader] of the Central Branch during the Defiance Campaign, was convicted and sentenced to twelve months with hard labour plus eight strokes by the Magistrate of Villa Nora.

33 The Government also made extensive use of the Suppression of Communism Act.

34 You will remember that in May last year the Government ordered Moses Kotane, Yusuf Dadoo, J. B. Marks, David Bopape and Johnson Ngwevela to resign from the Congresses and many other organisations and were also prohibited from attending political gatherings.

35 In consequence of these bans, Moses Kotane, J. B. Marks, and David Bopape did not attend our last provincial Conference.

36 In December last year, the Secretary General, Mr. W. M. Sisulu, and I were banned from attending gatherings and confined to Johannesburg for six months.

37 Early this year, the President-General, Chief Luthuli, whilst in the midst of a national tour which he was prosecuting with remarkable energy and devotion, was prohibited for a period of twelve months from attending public gatherings and from visiting Durban, Johannesburg, Cape Town, Port Elizabeth and many other centres.

38 A few days before the President-General was banned, the President of the SAIC, Dr. G. M. Naicker, had been served with a similar notice.

39 Many other active workers both from the African and Indian Congresses and from trade union organisations were also banned.

40 The Congresses realised that these measures created a new situation which did not prevail when the Campaign was launched in June 1952.

41 The tide of defiance was bound to recede and we were forced to pause and to take stock of the new situation.

42 We had to analyse the dangers that faced us, formulate plans to overcome them and evolve new plans of political struggle.

43 A political movement must keep in touch with reality and the prevailing conditions.

44 Long speeches, the shaking of fists, the banging of tables and strongly worded resolutions out of touch with the objective conditions do not bring about mass action and can do a great deal of harm to the organisation and the struggle we serve.

45 The masses had to be prepared and made ready for new forms of political struggle.

46 We had to recuperate our strength and muster our forces for another and more powerful offensive against the enemy.

47 To have gone ahead blindly as if nothing had happened would have been suicidal and stupid.

48 The conditions under which we meet today are, therefore, vastly different.

49 The Defiance Campaign together with its thrills and adventures has receded.

50 The old methods of bringing about mass action through public mass meetings, press statements and leaflets calling upon the people to go to action have become extremely dangerous and difficult to use effectively.

51 The authorities will not easily permit a meeting called under the auspices of the ANC, few newspapers will publish statements openly criticising the policies of the Government and there is hardly a single printing press which will agree to print leaflets calling upon workers to embark on industrial action for fear of prosecution under the Suppression of Communism Act and similar measures.

52 These developments require the evolution of new forms of political struggle which will make it reasonable for us to strive for action on a higher level than the Defiance Campaign.

53 The Government, alarmed at the indomitable upsurge of national consciousness, is doing everything in its power to crush our movement by removing the genuine representatives of the people from the organisations.

54 According to a statement made by Swart in Parliament on the 1 8th September, 1953, there are thirtythree trade union officials and eighty-nine other people who have been served with notices in terms of the Suppression of Communism Act.

55 This does not include that formidable array of freedom fighters who have been named and blacklisted under the Suppression of Communism Act and those who have been banned under the Riotous Assemblies Act.

56 Meanwhile the living conditions of the people, already extremely difficult, are steadily worsening and becoming unbearable.

57 The purchasing power of the masses is progressively declining and the cost of living is rocketing.

58 Bread is now dearer than it was two months ago.

59 The cost of milk, meat and vegetables is beyond the pockets of the average family and many of our people cannot afford them.

60 The people are too poor to have enough food to feed their families and children. 
61 They cannot afford sufficient clothing, housing and medical care.

62 They are denied the right to security in the event of unemployment, sickness, disability, old age and where these exist, they are of an extremely inferior and useless nature.

63 Because of lack of proper medical amenities our people are ravaged by such dreaded diseases as tuberculosis, venereal disease, leprosy, pellagra, and infantile mortality is very high.

64 The recent state budget made provision for the increase of the cost-of-living allowances for Europeans and not a word was said about the poorest and most hard-hit section of the population - the African people.

65 The insane policies of the Government which have brought about an explosive situation in the country have definitely scared away foreign capital from South Africa and the financial crisis through which the country is now passing is forcing many industrial and business concerns to close down, to retrench their staffs and unemployment is growing every day.

66 The farm labourers are in a particularly dire plight.

67 You will perhaps recall the investigations and exposures of the semi-slave conditions on the Bethal farms made in 1948 by the Reverend Michael Scott and a Guardian Correspondent; by the Drum last year and the Advance in April this year.

68 You will recall how human beings, wearing only sacks with holes for their heads and arms, never given enough food to eat, slept on cement floors on cold nights with only their sacks to cover their shivering bodies.

69 You will remember how they are woken up as early as 4 a.m. and taken to work on the fields with the indunassjambokking those who tried to straighten their backs, who felt weak and dropped down because of hunger and sheer exhaustion.

70 You will also recall the story of human beings toiling pathetically from the early hours of the morning till sunset, fed only on mealie meal served on filthy sacks spread on the ground and eating with their dirty hands.

$71 \quad$ People falling ill and never once being given medical attention.

72 You will also recall the revolting story of a farmer who was convicted for tying a labourer by his feet from a tree and had him flogged to death, pouring boiling water into his mouth whenever he cried for water.

73 These things which have long vanished from many parts of the world still flourish in SA today.

74 None will deny that they constitute a serious challenge to Congress and we are in duty bound to find an effective remedy for these obnoxious practices.

75 The Government has introduced in Parliament the Native Labour (Settlement of Disputes) Bill and the Bantu Education Bill.

76 Speaking on the Labour Bill, the Minister of Labour, Ben Schoeman, openly stated that the aim of this wicked measure is to bleed African trade unions to death.

77 By forbidding strikes and lockouts it deprives Africans of the one weapon the workers have to improve their position.

78 The aim of the measure is to destroy the present African trade unions which are controlled by the workers themselves and which fight for the improvement of their working conditions in return for a Central Native Labour Board controlled by the Government and which will be used to frustrate the legitimate aspirations of the African worker.

79 The Minister of Native Affairs, Verwoerd, has also been brutally clear in explaining the objects of the Bantu Education Bill.

80 According to him the aim of this law is to teach our children that Africans are inferior to Europeans.

81 African education would be taken out of the hands of people who taught equality between black and white.

82 When this Bill becomes law, it will not be the parents but the Department of Native Affairs which will decide whether an African child should receive higher or other education.

83 It might well be that the children of those who criticise the Government and who fight its policies will almost certainly be taught how to drill rocks in the mines and how to plough potatoes on the farms of Bethal.

84 High education might well be the privilege of those children whose families have a tradition of collaboration with the ruling circles.

85 The attitude of the Congress on these bills is very clear and unequivocal.

86 Congress totally rejects both bills without reservation.

87 The last provincial Conference strongly condemned the then proposed Labour Bill as a measure designed to rob the African workers of the universal right of free trade unionism and to undermine and destroy the existing African trade unions.

88 Conference further called upon the African workers to boycott and defy the application of this sinister scheme which was calculated to further the exploitation of the African worker.

89 To accept a measure of this nature even in a qualified manner would be a betrayal of the toiling masses.

90 At a time when every genuine Congressite should fight unreservedly for the recognition of African trade unions and the realisation of the principle that everyone has the right to form and to join trade unions for the protection of his interests, we declare our firm belief in the principles enunciated in the Universal Declaration of Human Rights that everyone has the right to education; that education shall 
be directed to the full development of human personality and to the strengthening of respect for human rights and fundamental freedoms.

91 It shall promote understanding, tolerance and friendship among the nations, racial or religious groups and shall further the activities of the United Nations for the maintenance of peace.

92

93

94

That parents have the right to choose the kind of education that shall be given to their children.

The cumulative effect of all these measures is to prop up and perpetuate the artificial and decaying policy of the supremacy of the white men.

The attitude of the government to us is that: "Let's beat them down with guns and batons and trample them under our feet.

We must be ready to drown the whole country in blood if only there is the slightest chance of preserving white supremacy.

"But there is nothing inherently superior about the herrenvolk idea of the supremacy of the whites. In China, India, Indonesia and Korea, American, British, Dutch and French Imperialism, based on the concept of the supremacy of Europeans over Asians, has been completely and perfectly exploded. In Malaya and Indo-China British and French imperialisms are being shaken to their foundations by powerful and revolutionary national liberation movements.

In Africa, there are approximately 190,000,000 Africans as against 4,000,000 Europeans.

The entire continent is seething with discontent and already there are powerful revolutionary eruptions in the Gold Coast, Nigeria, Tunisia, Kenya, the Rhodesias and South Africa.

The oppressed people and the oppressors are at loggerheads.

The day of reckoning between the forces of freedom and those of reaction is not very far off.

I have not the slightest doubt that when that day comes truth and justice will prevail.

The intensification of repressions and the extensive use of the bans is designed to immobilise every active worker and to check the national liberation movement.

But gone forever are the days when harsh and wicked laws provided the oppressors with years of peace and quiet.

6 The racial policies of the Government have pricked the conscience of all men of good will and have aroused their deepest indignation.

The feelings of the oppressed people have never been more bitter.

If the ruling circles seek to maintain their position by such inhuman methods then a clash between the forces of freedom and those of reaction is certain.

The feelings of the oppressed people have never been more bitter.

If the ruling circles seek to maintain their position by such inhuman methods then a clash between the forces of freedom and those of reaction is certain.

The grave plight of the people compels them to resist to the death the stinking policies of the gangsters that rule our country.

But in spite of all the difficulties outlined above, we have won important victories.

The general political level of the people has been considerably raised and they are now more conscious of their strength.

Action has become the language of the day.

The ties between the working people and the Congress have been greatly strengthened.

This is a development of the highest importance because in a country such as ours a political organisation that does not receive the support of the workers is in fact paralysed on the very ground on which it has chosen to wage battle.

Leaders of trade union organisations are at the same time important officials of the provincial and local branches of the ANC In the past we talked of the African, Indian and Coloured struggles.

Though certain individuals raised the question of a united front of all the oppressed groups, the various non-European organisations stood miles apart from one another and the efforts of those for co-ordination and unity were like a voice crying in the wilderness and it seemed that the day would never dawn when the oppressed people would stand and fight together shoulder to shoulder against a common enemy.

Today we talk of the struggle of the oppressed people which, though it is waged through their respective autonomous organisations, is gravitating towards one central command.

Our immediate task is to consolidate these victories, to preserve our organisations and to muster our forces for the resumption of the offensive.

1 To achieve this important task the National Executive of the ANC in consultation with the National Action Committee of the ANC and the SAIC formulated a plan of action popularly known as the "M" Plan and the highest importance is [given] to it by the National Executives.

Instructions were given to all provinces to implement the "M" Plan without delay.

The underlying principle of this plan is the understanding that it is no longer possible to wage our struggle mainly on the old methods of public meetings and printed circulars.

The aim is:

1. to consolidate the Congress machinery;

2. to enable the transmission of important decisions taken on a national level to every member of the organisation without calling public meetings, issuing press statements and printing circulars;

3. to build up in the local branches themselves local Congresses which will effectively represent the strength and will of the people; 
128 4. to extend and strengthen the ties between Congress and the people and to consolidate Congress leadership.

129 This plan is being implemented in many branches not only in the Transvaal but also in the other provinces and is producing excellent results.

130 The Regional Conferences held in Sophiatown, Germiston, Kliptown and Benoni on the 28th June, 23rd and 30th August and on the 6th September, 1953, which were attended by large crowds, are a striking demonstration of the effectiveness of this plan, and the National Executives must be complimented for it.

131 I appeal to all members of the Congress to redouble their efforts and play their part truly and well in its implementation.

132 The hard, dirty and strenuous task of recruiting members and strengthening our organisation through a house to house campaign in every locality must be done by you all.

133 From now on the activity of Congressites must not be confined to speeches and resolutions. Their activities must find expression in wide scale work among the masses, work which will enable them to make the greatest possible contact with the working people.

134 You must protect and defend your trade unions.

135 If you are not allowed to have your meetings publicly, then you must hold them over your machines in the factories, on the trains and buses as you travel home.

136 You must have them in your villages and shantytowns.

137 You must make every home, every shack and every mud structure where our people live, a branch of the trade union movement and never surrender.

138 You must defend the right of African parents to decide the kind of education that shall be given to their children.

139 Teach the children that Africans are not one iota inferior to Europeans.

140 Establish your own community schools where the right kind of education will be given to our children.

141 If it becomes dangerous or impossible to have these alternative schools, then again you must make every home, every shack or rickety structure a centre of learning for our children.

142 Never surrender to the inhuman and barbaric theories of Verwoerd.

143 The decision to defy the unjust laws enabled Congress to develop considerably wider contacts between itself and the masses and the urge to join Congress grew day by day.

144 But due to the fact that the local branches did not exercise proper control and supervision, the admission of new members was not carried out satisfactorily.

145 No careful examination was made of their past history and political characteristics.

146 As a result of this, there were many shady characters ranging from political clowns, place-seekers, splitters, saboteurs, agents-provocateurs to informers and even policemen, who infiltrated into the ranks of Congress.

147 One need only refer to the Johannesburg trial of Dr.Moroka and nineteen others, where a member of Congress who actually worked at the National Headquarters, turned out to be a detective-sergeant on special duty.

148 Remember the case of Leballo of Brakpan who wormed himself into that Branch by producing faked naming letters from the Liquidator, De Villiers Louw, who had instructions to spy on us.

149 There are many other similar instances that emerged during the Johannesburg, Port Elizabeth and Kimberley trials.

150 Whilst some of these men were discovered there are many who have not been found out.

151 In Congress there are still many shady characters, political clowns, place-seekers, saboteurs, provocateurs, informers and policemen who masquerade as progressives but who are in fact the bitterest enemies of our organisation.

152 Outside appearances are highly deceptive and we cannot classify these men by looking at their faces or by listening to their sweet tongues or their vehement speeches demanding immediate action.

153 The friends of the people are distinguishable by the ready and disciplined manner in which they rally behind their organisation and their readiness to sacrifice when the preservation of the organisation has become a matter of life and death.

154 Similarly, enemies and shady characters are detected by the extent to which they consistently attempt to wreck the organisation by creating fratricidal strife, disseminating confusion and undermining and even opposing important plans of action to vitalise the organisation.

155 In this respect it is interesting to note that almost all the people who oppose the "M" Plan are people who have consistently refused to respond when sacrifices were called for, and whose political background leaves much to be desired.

156 These shady characters by means of flattery, bribes and corruption, win the support of the weakwilled and politically backward individuals, detach them from Congress and use them in their own interests.

157 The presence of such elements in Congress constitutes a serious threat to the struggle, for the capacity for political action of an organisation which is ravaged by such disruptive and splitting elements is considerably undermined.

158 Here in South Africa, as in many parts of the world, a revolution is maturing: it is the profound desire, the determination and the urge of the overwhelming majority of the country to destroy forever the 
shackles of oppression that condemn them to servitude and slavery.

159 To overthrow oppression has been sanctioned by humanity and is the highest aspiration of every free man.

160 If elements in our organisation seek to impede the realisation of this lofty purpose then these people have placed themselves outside the organisation and must be put out of action before they do more harm.

161 To do otherwise would be a crime and a serious neglect of duty.

162 We must rid ourselves of such elements and give our organisation the striking power of a real militant mass organisation.

163 Kotane, Marks, Bopape, Tloome and I have been banned from attending gatherings and we cannot join and counsel with you on the serious problems that are facing our country.

164 We have been banned because we champion the freedom of the oppressed people of our country and because we have consistently fought against the policy of racial discrimination in favour of a policy which accords fundamental human rights to all, irrespective of race, colour, sex or language.

165 We are exiled from our own people for we have uncompromisingly resisted the efforts of imperialist America and her satellites to drag the world into the rule of violence and brutal force, into the rule of the napalm, hydrogen and the cobalt bombs where millions of people will be wiped out to satisfy the criminal and greedy appetites of the imperial powers.

166 We have been gagged because we have emphatically and openly condemned the criminal attacks by the imperialists against the people of Malaya, Vietnam, Indonesia, Tunisia and Tanganyika and called upon our people to identify themselves unreservedly with the cause of world peace and to fight against the war policies of America and her satellites.

167 We are being shadowed, hounded and trailed because we fearlessly voiced our horror and indignation at the slaughter of the people of Korea and Kenya.

168 The massacre of the Kenya people by Britain has aroused world-wide indignation and protest.

169 Children are being burnt alive, women are raped, tortured, whipped and boiling water poured on their breasts to force confessions from them that Jomo Kenyatta had administered the Mau Mau oath to them.

170 Men are being castrated and shot dead.

171 In the Kikuyu country there are some villages in which the population has been completely wiped out.

172 We are prisoners in our own country because we dared to raise our voices against these horrible atrocities and because we expressed our solidarity with the cause of the Kenya people.

173 You can see that "there is no easy walk to freedom anywhere, and many of us will have to pass through the valley of the shadow (of death) again and again before we reach the mountain tops of our desires.

174 "Dangers and difficulties have not deterred us in the past, they will not frighten us now.

175 But we must be prepared for them like men in business who do not waste energy in vain talk and idle action.

176 The way of preparation (for action) lies in our rooting out all impurity and indiscipline from our organisation and making it the bright and shining instrument that will cleave its way to (Africa's) freedom." 